\title{
PENGARUH AIR LINDI PADA TERHADAP pH DAN ZAT ORGANIK PADA AIR TANAH DI TEMPAT PENAMPUNGAN SEMENTARA KELURAHAN PAHANDUT KOTA PALANGKARAYA (Effect of Leachate to $\mathrm{pH}$ and Organic Substances of Ground Water in The Waste Transfer Station in Kelurahan Pahandut Kota Palangka Raya)
}

\author{
Nani Apriyani* dan Rudy Yoga Lesmana \\ Program Studi Teknik Lingkungan, Fakultas Teknik Universitas Muhammadiyah Palangkaraya, \\ Jalan RTA Milono Km. 1,5, Palangka Raya, 73111.
}

*Penulis korespondensi. Tel: 085249256569. Email: naniapriyani@ umpalangkaraya.ac.id.

\author{
Diterima: 24 Maret 2018
}

Disetujui: 20 Mei 2018

\begin{abstract}
Abstrak
Tumpukan sampah di Tempat Penampungan Sementara (TPS) maupun Tempat Pemrosesan Akhir (TPA) yang menghasilkan air lindi perlu dilakukan pemantauan untuk mengetahui air lindi sebelum dibuang guna mencegah terjadinya pencemaran air tanah. Penelitian ini bertujuan mengetahui pengaruh dari kualitas air lindi terhadap air tanah warga di sekitar lokasi TPS di Kelurahan Pahandut, Kota Palangka Raya. Penelitian dilakukan dengan melakukan pemeriksaan parameter air lindi, seperti Total Suspended Solid (TSS), Dissolved Oxygen (DO), kandungan minyak dan lemak. Selain itu, parameter kualitas air tanah juga diperiksa, seperti pH dan kadar zat organik pada 2 titik lokasi dengan jarak masing-masing 50 meter. Hasil penelitian menunjukkan bahwa kadar TSS air lindi di sekitar TPS melebihi baku mutu yaitu $130 \mathrm{ppm}$ dan berpotensi sebagai penyebab tercemarnya air tanah di lokasi sekitar TPS tersebut. Kadar zat organik air tanah pada titik 1 dan 2 melebihi baku mutu yaitu sebesar 17 dan 15,1 ppm dari baku mutu yang diharapkan $10 \mathrm{ppm}$ serta $\mathrm{pH}$ yang di bawah rentang $\mathrm{pH}$ yang diizinkan yaitu 6,5-9.
\end{abstract}

Kata kunci: air lindi, air tanah, TSS, pH, zat organik, pencemaran, sampah domestik.

\begin{abstract}
Piles of domestic waste in Temporary waste transfer station (TPS) and Final Processing Station (TPA) that produce leachate need to be monitored to find out the leachate before disposal to prevent contamination of groundwater. This study aims to determine the effect of leachate water quality on groundwater of residents around the TPS location in Pahandut Village, Palangka Raya City. The study was conducted by examining the leachate quality parameters, such as Total Suspended Solid (TSS), Dissolved Oxygen (DO), oil and fat content, and also examining the groundwater quality parameters, such as $\mathrm{pH}$ and organic matter at two water samples from two locations of sampling site with a distance of 50 meters. The results showed that the TSS value of leachate was 130 ppm, which exceeded the permitted quality standard. It can lead groundwater pollution in area around the TPS. The organic substance levels of two site of groundwater exceeded the groundwater quality standards, 17 and 15.1 ppm respectively. The pH of two site of groundwater was 6.5-9, which was below the groundwater quality standards.
\end{abstract}

Keywords: leachate, ground water, TSS, pH, organic substance, pollution, domestic waste.

\section{PENDAHULUAN}

Peningkatan aktivitas manusia sebagai dampak laju pertumbuhan penduduk yang semakin tinggi saat ini menyebabkan semakin banyaknya buangan hasil dari aktivitas tersebut, baik berupa padatan, cairan maupun gas. Salah satu buangan yang terlihat langsung adalah timbulan sampah. Tanpa disadari hal ini dapat menyebabkan semakin menurunnya kualitas lingkungan hidup akibat pencemaran. Salah satu contoh pencemaran yang terjadi adalah kasus pencemaran air tanah yang diakibatkan oleh jumlah timbulan sampah. Sementara itu, kualitas dan kuantitas air tanah pada daerah permukiman harus terjamin agar dapat digunakan untuk keperluan hidup sehari-hari bagi masyarakat sesuai dengan standar kesehatan dan baku mutu kualitas air (Harmayani dan Konsukartha, 2007).

Ketidaktepatan pengelolaan sampah di permukiman penduduk sangat berpotensi terhadap pencemaran air tanah. Hal ini menjadi alasan perlunya pengelolaan sampah khususnya di Tempat Penampungan Sementara (TPS) dan Tempat Pemrosesan Akhir (TPA) dengan sistem pembuangan limbah yang dapat menampung, mengolah dan mengalirkan limbah tersebut secara baik dan benar sebelum dilepas ke lingkungan. Saat ini jumlah timbulan sampah di TPA akan terus meningkat dan jika tidak diimbangi dengan kegiatan pengolahan dan pemanfaatan sampah di tingkat masyarakat, maka dikhawatirkan akan 
berpotensi menimbulkan pencemaran air tanah. Oleh karena itu perlu adanya kegiatan pengelolaan sampah untuk mengurangi beban TPA yang dilakukan mendekati sumber sampah, salah satunya di TPS (Rahmaniah, 2013).

Jumlah timbulan sampah yang ada di TPS menjadi berpotensi mencemari air tanah karena faktor air lindi yang keluar dari sampah tersebut. Air lindi adalah cairan yang merembes melalui tumpukan sampah dengan membawa yang mengandung materi terlarut atau tersuspensi (Damanhuri dan Tri, 2010). Lindi dapat meresap ke dalam tanah sehingga dapat menyebabkan pencemaran tanah dan air tanah secara langsung karena dalam lindi terdapat berbagai senyawa kimia organik, anorganik dan sejumlah patogen (Susanto dkk, 2004).

Air lindi terbentuk dalam timbunan sampah dan mengandung banyak senyawa dengan kadar pencemar yang tinggi khususnya zat organik. Air lindi selanjutnya akan mengisi rongga-rongga pada sampah yang jika kapasitasnya melampaui kapasitas tekanan air dari sampah, maka air lindi akan keluar dan mengekstraksi bahan organik dan anorganik hasil proses físika, kimia dan biologis yang terjadi pada timbulan sampah (Pinem, 2014). Sari dan Afdal (2017) melaporkan bahwa kualitas air lindi di TPA Air Dingin Kota Padang masih kurang efektif karena beberapa parameter kualitas air lindi yang jauh di atas baku mutu yaitu konduktivitas listrik, padatan total terlarut (Total Dissolve Solid, TDS), $\mathrm{pH}$ dan kandungan logam berat $\mathrm{Pb}, \mathrm{Cu}$ dan $\mathrm{Fe}$. Hubungan penyebaran lindi TPA Sumurbatu terhadap kualitas air tanah di Kelurahan Sumurbatu Kecamatan Bantar Gebang yang dilaporkan oleh Arum dkk (2017) menunjukkan bahwa terdapat hubungan penyebaran lindi dengan kadar nitrat air tanah. Kualitas air sumur di sekitar TPA Galuga Kabupaten Bogor menunjukkan kondisi pH asam, kebutuhan oksigen biologis (Biological Oxigen Demand, BOD), kebutuhan oksigen kimiawi (Chemically Oxigen Demand, COD), dan total coliform sangat tinggi. Kualitas perairan saluran buangan lindi dan perairan umum sekitarnya termasuk kriteria sedang sampai dengan buruk (Priambodho, 2005).

Secara umum, karakteristik air lindi di suatu TPS atau TPA bervariasi bergantung pada komposisi sampah dan kondisi geografis wilayah tersebut. Salah satu kota di Indonesia yang berpotensi mengalami pencemaran air tanah akibat timbulan sampah adalah Kota Palangka Raya. Kelurahan Pahandut Kota Palangka Raya merupakan wilayah yang padat penduduk. Kondisi saat ini menyebutkan bahwa timbulan sampah di Kota Palangka Raya mencapai 119,1 ton per hari, sedangkan daya angkut ke TPA hanya sekitar 57 ton per hari (Disciptarum Kota Palangka Raya). Data ini menunjukkan perlu adanya tindakan identifikasi terhadap potensi pencemaran air tanah akibat timbulan sampah. Hal ini perlu dilakukan agar dapat dijadikan bahan pertimbangan bagi stakeholder untuk pengambilan keputusan di kemudian hari dalam rangka mitigasi bahaya pencemaran air tanah di Kota Palangka Raya.

\section{METODE PENELITIAN}

\section{Waktu dan Lokasi}

Pengambilan sampel penelitian dilakukan pada 24 Januari 2018 berupa air lindi dan air tanah. Air lindi diambil dari Tempat Penampungan Sementara (TPS) yang berlokasi di Kelurahan Pahandut Kota Palangka Raya, yaitu Unit Pelaksana Teknis (UPT) Pengelolaan Sampah Terpadu (PST) Kelurahan Pahandut Kota Palangka Raya. Sampel air tanah diambil dari kran air warga sekitar lokasi TPS yang menggunakan sumur bor. Peta lokasi penelitian dapat dilihat pada Gambar 1.

Prosedur penelitian dimulai dengan penentuan titik lokasi pengambilan sampel air tanah yaitu 2 titik dengan jarak masing-masing titik adalah $50 \mathrm{~m}$ dengan pengukuran posisi (elevasi) dan koordinat menggunakan GPS. Sampel air lindi diambil di kolam penampungan air lindi yang ada di TPS lokasi penelitian. Parameter kualitas air lindi yang diperiksa adalah $\mathrm{pH}$, Total Suspensed Solid (TSS), Disolved Oxygen (DO) serta minyak dan lemak, sedangkan air tanah menggunakan parameter $\mathrm{pH}$ dan kadar zat organik. Pemeriksaan $\mathrm{pH}$ air lindi dan air tanah dilakukan secara langsung di lapangan, sedangkan pemeriksaan parameter lainnya dilakukan di Laboratorium Kesehatan Daerah Provinsi Kalimantan Tengah dengan metode analisis seperti di Tabel 1.

\section{Analisis Data}

Data yang diperoleh berupa keadaan posisi (elevasi) dan koordinat pada titap titik pengambilan sampel serta data kualitas air lindi dan air tanah. Data posisi dan koordinat lokasi pengambilan sampel digunakan untuk menganalisis keterkaitan antara ketingiian lokasi dengan potensi pencemaran. Data kualitas air lindi dan air tanah digunakan untuk mengetahui keterimaan kadarnya terhadap nilai baku mutu yang diizinkan. Baku mutu yang digunakan untuk air lindi berdasarkan Peraturan Menteri Lingkungan Hidup Republik Indonesia Nomor 5 Tahun 2014 tentang Baku Mutu Air Limbah bagi Usaha dan/atau Kegiatan Domestik. Data kualitas air tanah dibandingkan dengan data Peraturan Menteri Kesehatan No. 32 Tahun 2017 tentang Standar Baku Mutu Kesehatan Lingkungan dan Persyaratan Kesehatan Air untuk 
Keperluan Higiene Sanitasi, Kolam Renang, Solusi Per Aqua dan Pemandian Umum.

\section{HASIL DAN PEMBAHASAN}

Hasil dari penelitian berupa data 2 titik lokasi pengambilan sampel air tanah dan data kadar dari paramater air lindi dan air tanah yang sudah ditentukan. Lokasi pengambilan sampel air tanah dilakukan pada tiga titik di sekitar TPS Kelurahan Pahandut Kota Palangka Raya dengan jarak masing-masing $50 \mathrm{~m}$ dengan rincian seperti pada Tabel 2.

Berdasarkan data tersebut dapat diketahui bahwa titik pengambilan sampel air tanah berada pada ketinggian berbeda, di mana ketinggian semakin berkurang dari titik 1 sampai titik 2 .

\section{Kualitas Air Lindi}

Secara pengamatan langsung, penampakan air lindi berwarna hitam dengan bau menyengat. Hasil pemeriksaan di laboratorium terhadap parameter kualitas air lindi yang telah ditentukan disajikan dalam Tabel 3.

Tabel 1. Prosedur analisis pemeriksaan sampel.

\begin{tabular}{lll}
\hline \multicolumn{1}{c}{ Parameter } & Satuan & \multicolumn{1}{c}{ Metode analisis } \\
\hline TSS & $\mathrm{mg} \mathrm{L}^{-1}$ & SNI 06.6989.3-2004 \\
DO & $\mathrm{mg} \mathrm{L}^{-1}$ & SNI 06-2425-1991 \\
Minyak dan lemak & $\mathrm{mg} \mathrm{L}^{-1}$ & SNI 06-6989.10-2004 \\
Zat Organik & $\mathrm{mg} \mathrm{L}^{-1}$ & SNI 06-6989.22:2004 \\
\hline
\end{tabular}

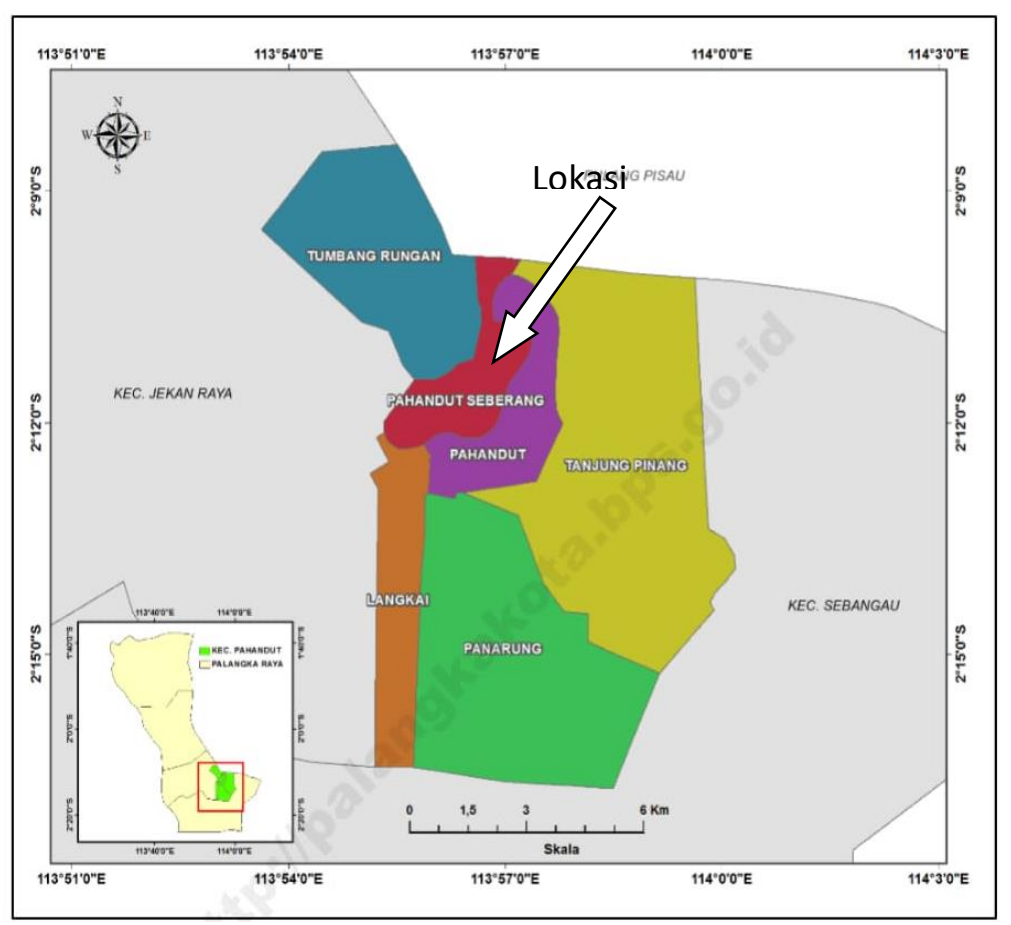

Gambar 1. Lokasi penelitian pada peta kecamatan di Kota Palangkaraya. (Sumber: Badan Pusat Statistik Kota Palangka Raya Tahun 2016).

Tabel 2. Titik lokasi pengambilan sampel air tanah.

\begin{tabular}{cccc}
\hline \multirow{2}{*}{ Titik } & \multirow{2}{*}{ Posisi (elevasi) } & \multicolumn{2}{c}{ Koordinat } \\
\cline { 3 - 4 } & & $\mathrm{S}$ & $\mathrm{E}$ \\
\hline 1 & $7 \mathrm{mdpl}$ & $02^{\circ} 12^{\prime} 14^{\prime \prime}$ & $113^{\circ} 56^{\prime} 12^{\prime \prime}$ \\
2 & $4 \mathrm{mdpl}$ & $02^{\circ} 12^{\prime} 15^{\prime \prime}$ & $113^{\circ} 56^{\prime} 19^{\prime \prime}$ \\
\hline
\end{tabular}

Tabel 3. Hasil pemeriksaan parameter kualitas air lindi

\begin{tabular}{cccc}
\hline Parameter & Satuan & Hasil pemeriksaan & Baku mutu \\
\hline $\mathrm{pH}$ & - & 7,54 & $6,5-9$ \\
TSS & $\mathrm{mg} \mathrm{L}^{-1}$ & 130 & 100 \\
DO & $\mathrm{mg} \mathrm{L}^{-1}$ & 0,37 & - \\
Minyak dan lemak & $\mathrm{mg} \mathrm{L}^{-1}$ & Tidak terdeteksi & 10 \\
\hline
\end{tabular}

Tabel 4. Hasil pemeriksaan parameter kualitas air tanah

\begin{tabular}{|c|c|c|c|c|}
\hline \multirow{2}{*}{ Parameter } & \multirow{2}{*}{ Satuan } & \multicolumn{2}{|c|}{ Titik } & \multirow{2}{*}{ Baku mutu } \\
\hline & & 1 & 2 & \\
\hline $\mathrm{pH}$ & - & 5,69 & 5,79 & $6,5-9$ \\
\hline Zat Organik & $\mathrm{mg} \mathrm{L}^{-1}$ & 17 & 15,1 & 10 \\
\hline
\end{tabular}


Berdasarkan Tabel 3 tersebut dapat dilihat bahwa air lindi di TPS tersebut tidak memenuhi baku mutu sebagai air limbah karena adanya parameter yang kadarnya melebihi baku mutu air limbah. Menurut Peraturan Menteri Lingkungan Hidup Republik Indonesia Nomor 5 Tahun 2014 tentang Baku Mutu Air Limbah bagi Usaha dan/atau Kegiatan Domestik, baku mutu air limbah adalah ukuran batas atau kadar unsur pencemar dan/atau jumlah unsur pencemar yang ditenggang keberadaannya dalam air limbah yang akan dibuang atau dilepas ke dalam media air dari suatu usaha dan/atau kegiatan.

Parameter yang melebihi baku mutu tersebut adalah Total Suspensed Solid (TSS) atau padatan tersuspensi total yaitu sebesar $130 \mathrm{mg} \mathrm{L}^{-1}$ dari baku mutu yang disyaratkan sebesar $100 \mathrm{mg} \mathrm{L}^{-1}$. TSS atau total suspended solid atau padatan tersuspensi total adalah residu dari padatan total yang tertahan oleh saringan dengan ukuran partikel maksimal 2 $\mu \mathrm{m}$ atau lebih besar dari ukuran partikel koloid. Yang termasuk TSS adalah lumpur, tanah liat, logam oksida, sulfida, ganggang, bakteri dan jamur. Zat yang tersuspensi biasanya terdiri dari zat organik dan anorganik yang melayang-layang dalam air, secara fisika zat ini sebagai penyebab kekeruhan pada air. Padatan tersuspensi merupakan tempat berlangsungnya reaksi kimia yang heterogen dan pembentuk endapan yang akan menghalangi kemampuan degradasi zat organik di suatu perairan. Penetrasi cahaya matahari ke permukaan dan bagian yang lebih dalam tidak berlangsung efektif akibat terhalang oleh zat padat tersuspensi.

Parameter minyak dan lemak tidak terdeteksi melalui pemeriksaan yang telah dilakukan yaitu berdasarkan prosedur Standar Nasional Indonesia (SNI) 06-6989.10-2004 dengan metode gravimetri. Metoda ini dapat digunakan untuk contoh uji yang mengandung minyak dan lemak lebih besar dari 10 mg L ${ }^{-1}$, sehingga dapat dikatakan bahwa kandungan minyak dan lemak dalam air lindi tidak mencapai $10 \mathrm{mg} \mathrm{L}{ }^{-1}$. Hal ini menunjukkan bahwa kadar minyak dan lemak air lindi masih memenuhi baku mutu.

Beberapa penelitian yang telah dilakukan juga menunjukkan adanya parameter kualitas air lindi yang tidak memenuhi baku mutu. Meskipun demikian, kualitas air lindi juga memiliki karakteristik yang berbeda-beda. Hal ini bergantung pada komposisi sampah dan proses yang terjadi dalam tumpukan sampah tersebut yang meliputi proses fisika, kimia dan biologi. Uji kualitas kimia pada air lindi di tempat pengolahan akhir sampah Santiago Tahuna dilakukan Pagiling dkk (2017) menunjukkan parameter DO, COD, BOD, dan Cd masih memenuhi baku mutu, sedangkan parameter
$\mathrm{NO}_{2}$ tidak memenuhi baku mutu. Astuti (2006) juga menemukan bahwa parameter BOD, COD, Cd, nitrat, nitrit, serta minyak dan lemak pada air lindi di TPA Sampah Putri Cempo Mojosongo Surakarta nilainya cukup tinggi.

Tingginya kadar TSS pada air lindi di TPS Kelurahan Pahandut Kota Palangka Raya dapat merupakan penyebab dari tingginya zat organik pada air tanah di sekitarnya. Hal ini terlihat dari data hasil pemeriksaan $\mathrm{pH}$ kadar zat organik pada sampel air tanah di titik 1, 2 dan 3 yang ditampilkan pada Tabel 4.

Secara organoleptik, air tanah sampel penelitian tidak berbau dan tidak berasa, namun parameter $\mathrm{pH}$ dan zat organik menunjukkan adanya nilai yang tidak memenuhi baku mutu. $\mathrm{pH}$ yang disyaratkan sebagai air bersih berada pada rentang 6,5-9 sedangkan hasil pemeriksaan menunjukkan $\mathrm{pH}$ yang di bawah rentang tersebut yaitu 5. Nilai pH 5 menunjukkan sifat keasaman yang cukup tinggi. Sampel air tanah diambil dari perumahan penduduk yang berada di sekitar TPS yang juga berada dekat dengan Sungai Kahayan. Asamnya $\mathrm{pH}$ pada air tanah sampel dapat disebabkan adanya pengaruh dari $\mathrm{pH}$ Sungai Kahayan yang berkisar antara 5,3-5,4 (Novrianti dkk, 2017).

Parameter zat organik pada juga tidak memenuhi baku mutu yang dipersyaratkan. Pemeriksaan zat organik pada penelitian ini dilakukan dengan prosedur SNI 06-6989.22:2004 yaitu pengujian nilai permanganat secara titrimetri. Prinsip prosedur ini adalah oksidasi zat organik di dalam air dengan $\mathrm{KMnO}_{4}$ direduksi oleh asam oksalat berlebih dan kelebihan asam oksalat dititrasi kembali dengan $\mathrm{KMnO}_{4}$. Zat organik pada sampel penelitian tidak memenuhi baku mutu yaitu lebih dari $10 \mathrm{mg} \mathrm{L}^{-1}$. Tingginya zat organik ini dapat disebabkan karena adanya rembesan air lindi yang berada pada posisi lebih tinggi daripada lokasi pengambilan sampel air tanah. Air lindi dengan kandungan TSS yang tinggi pada hasil pengujian di penelitian ini dapat merembes melalui aliran bawah tanah. Sulitnya penetrasi sinar matahari pada larutan dengan kadar TSS tinggi menyebabkan zat organik sulit terurai sehingga mencemari air tanah. Gambar 2 dan 3 berikut menunjukkan $\mathrm{pH}$ dan zat organik sampel air tanah yang tidak memenuhi baku mutu.

Gambar 2 dan 3 tersebut menunjukkan perbedaan rentang antara hasil pemeriksaan dengan baku mutu. Zat organik pada titik 2 lebih rendah daripada pada titik 1 dikarenakan posisinya yang lebih jauh dari TPS sehingga memungkinkan kadar zat organik mengalami pengurangan akibat pengenceran oleh air dalam tanah. Beberapa kasus pencemaran air tanah juga ditemukan akibat adanya 


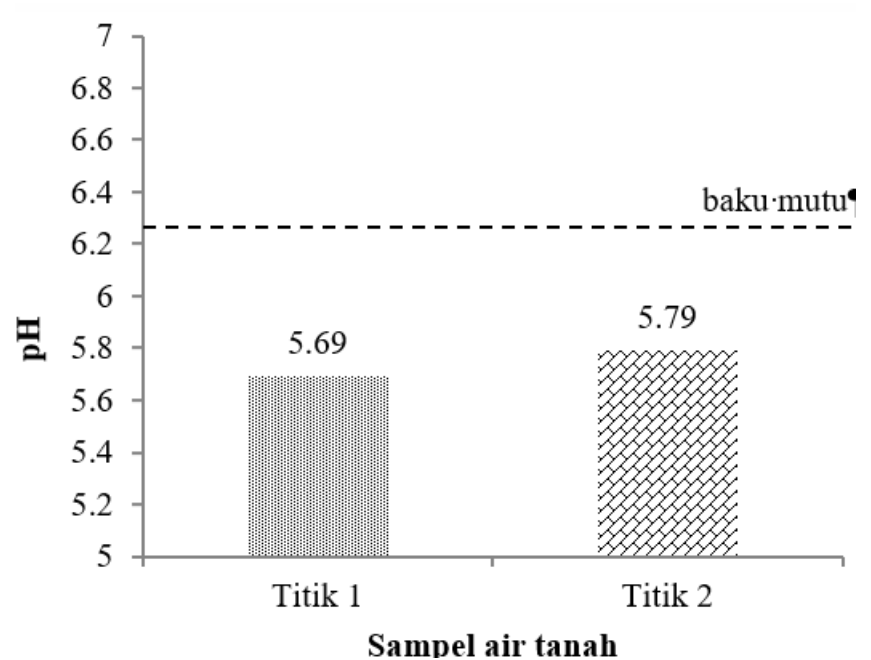

Gambar 2. Hasil pemeriksaan parameter $\mathrm{pH}$.

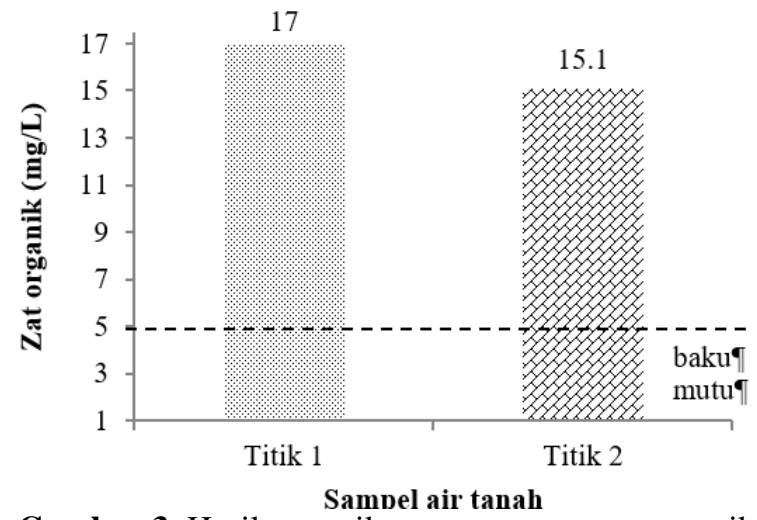

Gambar 3. Hasil pemeriksaan parameter zat organik.

tempat pembuangan sampah di sekitar lokasi. Hasil penelitian Amirah (2012) menunjukkan konsentrasi amonia yang tidak memenuhi baku mutu bagi air tanah di sekitar TPS sampah Batu Ampar pada jarak $15 \mathrm{~m}$ sampai $100 \mathrm{~m}$ dari lokasi TPS. Hal senada juga dilaporkan oleh Kurniawan (2006) bahwa hasil pengukuran parameter fisik, kima dan mikrobiologi air sumur di wilayah sekitar TPA Galuga menunjukkan ada 11 parameter yang telah melampaui ambang batas maksimum yang diperbolehkan menurut persyaratan Baku Mutu air kelas I, yaitu bau, rasa, pH, DO, BOD, COD, amonia, nitrit, seng, bakteri coliform dan fecal coli (E. coli) dengan nilai indeks kualitas air rata-rata untuk seluruh lokasi pengamatan adalah 48,65 (buruk). Penelitian di TPA Air Dingin yang dilakukan Yatim (2013) mengeni pengaruh lindi terhadap air sumur penduduk di sekitar TPA Air Dingin menyatakan beberapa parameter seperti TSS, COD dan BOD telah melebihi batas baku mutu dan telah mempengaruhi kualitas air sumur penduduk sekitar. Zat organik merupakan salah satu penyebab terjadinya pencemaran air. Yudhyarto (2015) melaporkan bahwa kualitas air di sekitar TPA Putri Cempo menunjukkan bahwa kualitas air sumur yang digunakan untuk kebutuhan sehari-hari tidak memenuhi baku mutu air minum karena kandungan total coliformnya yang di atas baku mutu. Faktor-faktor yang menyebabkan tercemarnya air adalah 47,62\% limbah rumah tangga, 33,33\% limbah industri dan 19,04\% limbah perkotaan (Widiyanto, dkk., 2015). Sebagian besar limbah rumah tangga merupakan zat organik.

\section{KESIMPULAN}

Kualitas air lindi yang tidak memenuhi baku mutu dapat menjadi penyebab tercemarnya air tanah di sekitar lokasi TPS. Selain itu, pencemaran air tanah ini juga dapat dipengaruhi oleh posisi geografis yaitu ketinggian dan kualitas air sungai di sekitar lokasi. Perlu dilakukan lagi penelitian secara berkala dan kontinyu untuk mendapatkan data yang lebih representatif mengenai kualitas air lindi dan air tanah di sekitar lokasi.

\section{UCAPAN TERIMAKASIH}

Ucapan terima kasih disampaikan kepada Kemenristekdikti yang telah memberikan pendanaan penuh pada penelitian ini melalui Hibah Penelitian Dosen Pemula Tahun Anggaran 2018 berdasarkan Surat Keputusan Lembaga Penelitian dan Pengabdian kepada Masyarakat (LP2M) Universitas Muhammdiyah Palangkaraya dan Surat Perjanjian Kontrak Penelitian bagi Dosen Tetap Universitas Muhammadiyah Palangkaraya Pembiayaan Kemenristekdikti Tahun Anggaran 2018 Nomor: 448.h/PTM.63.R10/LP2M/N/2018.

\section{DAFTAR PUSTAKA}

Amirah, 2012. Pengaruh Timbunan Sampah di Lahan Terbuka Terhadap Kualitas Air Tanah di Sekitar TPS Sementara Kelurahan Batu Ampar. Skripsi. Fakultas Teknik. Universitas Indonesia, Jakarta.

Anonim, 2014. Peraturan Menteri Lingkungan Hidup Republik Indonesia Nomor 5 Tahun 2014 tentang Baku Mutu Air Limbah bagi Usaha dan/atau Kegiatan Domestik. Jakarta.

Anonim, 2017. Peraturan Menteri Kesehatan No. 32 Tahun 2017 tentang Standar Baku Mutu Kesehatan Lingkungan dan Persyaratan Kesehatan Air untuk Keperluan Higiene Sanitasi, Kolam Renang, Solusi Per Aqua dan Pemandian Umum. Jakarta.

Arum, A.R., Rahardjo, M., dan Yunita, N.A., 2017. Analisis Hubungan Penyebaran Lindi TPA Sumurbatu terhadap Kualitas Air Tanah di Kelurahan Sumurbatu Kecamatan Bantar 
Gebang Bekasi Tahun 2017. Jurnal Kesehatan Masyarakat. 5(5) 461-469.

Astuti, D., 2006. Analisis Kualitas Air Lindi di Tempat Pembuangan Akhir Sampah Putri Cempo Mojosongo Surakarta. Jurnal Kesehatan, 2(2).

Damanhuri, E.,dan Tri, P., 2010. Pengelolaan Sampah. Institut Teknologi Bandung, Bandung.

Harmayani, D.K., dan Konsukartha, I.G.M., 2007. Pencemaran Air Tanah Akibat Pembuangan Limbah Domestik di Lingkungan Kumuh Studi Kasus Banjar Ubung Sari, Kelurahan Ubung. Jurnal Permukiman Natah. 5(2):92108.

Kurniawan, B., 2006. Analisis Kualitas Air Sumur Sekitar Wilayah Tempat Pembuangan Akhir Sampah (Studi Kasus di TPA Galuga Cibungbulang Bogor). Skripsi. Fakultas Teknologi Pertanian, Institut Pertanian Bogor, Bogor.

Pagiling, S., Akili, R.H., dan Umboh, J.M.L., 2017. Uji Kualitas Kimia pada Air Lindi di Tempat Pengolahan Akhir Sampah Santiago Tahuna Tahun 2017. Artikel Hasil Penelitian. Fakultas Kesehatan Masyarakat Universitas Sam Ratulangi.

Pinem, J.A., Ginting, M.S., dan Peratenta, M., 2014. Pengolahan Air Lindi TPA Muara Fajar dengan Ultrafiltrasi. Jurnal Teknobiologi, $5(1): 43-46$.

Priambodho, K., 2005. Kualitas Air Lindi pada Tempat Pembuangan Akhir Sampah Galuga
Kabupaten Bogor. Skripsi. Departemen Manajemen Sumberdaya Perairan Fakultas Perikanan dan Ilmu Kelautan, Institut Pertanian Bogor. Bogor.

Rahmaniah, R., Meidiana, C., dan Ari, I.R.D., 2013. Potensi Reduksi Sampah Melalui Pengelolaan Sampah Perkotaan Di TPS Kecamatan Mataram. Jurnal Tata Kota dan Daerah. 5(5):119.

Sari, R.N., dan Afdal, 2017. Karakteristik Air Lindi (Leachate) di Tempat Pembuangan Akhir Sampah Air Dingin Kota Padang. Jurnal Fisika Unand. 6(1):93-99.

Susanto, P.J., Ganefati P.S., Muryani, S., dan Istiqomah, H.S., 2004. Pengolahan Lindi (Leachate) dari TPA dengan Menggunakan Sistem Koagulasi Biofilter Anaerobic. Jurnal Teknologi Lingkungan, 5:167-173.

Widiyanto, A.F., Yuniarno, S., dan Kuswanto, 2015. Polusi Air Tanah Akibat Limbah Industri dan Limbah Rumah Tangga. Jurnal Kesehatan Masyarakat, 10(2):246-254.

Yatim, E. M., dan Mukhlis, 2013. Pengaruh Lindi (Leachate) Sampah Terhadap Air Sumur Penduduk Sekitar Tempat Pembuangan Akhir (TPA) Air Dingin. Jurnal Kesehatan Masyarakat, 7(2):54-59.

Yudhyarto, B., Utomo, B., dan Sulastoro, 2015. Pengaruh Tempat Pembuangan Akhir Sampah Putri Cempo Surakarta Terhadap Kualitas Air Tanah Dangkal Penduduk Sekitar. e-Jurnal Matriks Teknik Sipil, 6:564-569. 